JEFFERSON FREIRE CARDOSO

\title{
RESISTÊNCIA DE UNIÃO DE DIFERENTES CIMENTOS À DENTINA INTRARRADICULAR SUBMETIDA A DIFERENTES PROTOCOLOS DE LIMPEZA
}

Dissertação constituída por artigo apresentada à Faculdade de Odontologia de Bauru da Universidade de São Paulo para obtenção do título de Mestre em Ciências no Programa de Ciências Odontológicas Aplicadas, na área de concentração em Reabilitação Oral.

Orientador: Prof. Dr. Accácio Lins do Valle

Coorientador: Prof. Dr. Jefferson Ricardo Pereira

BAURU

2020 


\section{RESUMO}

O objetivo deste estudo foi avaliar a resistência de união $(R U)$ de diferentes sistemas usados para cimentar pinos de fibra de vidro (PFV) à dentina intrarradicular submetida a diferentes protocolos de limpeza. Setenta e dois dentes humanos com comprimentos radiculares semelhantes foram divididos randomicamente em dois grupos $(n=36)$, de acordo com o protocolo de limpeza, convencional $(\mathrm{NaOCl} 2.5 \%+$ EDTA $17 \%$ ) ou ativado ( $\mathrm{NaOCl} 2.5 \%$ + Irrigação passiva ultrassônica) e após, em três subgrupos para cada protocolo $(n=12)$ de acordo com o tipo de cimento avaliado (Civ: Meron; Ultimate: RelyX Ultimate e U200: RelyX U200). Após preparo padronizado do espaço para PFV, a dentina intrarradicular recebeu tratamento com sistema adesivo para o cimento resinoso dual convencional e nenhum tratamento para os outros cimentos. Rhodamina foi incorporada ao sistema de cimentação previamente a inserção do PFV. Em seguida, amostras dos terços cervical, médio e apical do espaço do PFV foram preparadas e analisadas usando um teste de RU push-out e microscopia confocal a laser (CLMS). ANOVA 3 critérios e teste LSD de Fisher mostraram que não houve diferença estatística significante entre os protocolos de limpeza ( $p=0.102$ ); Entretanto entre os cimentos, os resultados de $R U$ foram semelhantes apenas no terço apical, enquanto nos terços médio e cervical, Ultimate e U200 apresentaram resultados semelhantes e superiores ao CIV $(p \leq 0.001)$. A porcentagem de penetração dos cimentos nos túbulos dentinários foi avaliada por meio de teste Kruskal-Wallis e não mostrou diferença estatística significativa entre os fatores $(P=0.076)$. Ambos os protocolos de limpeza se mostraram efetivos e o cimento RelyX U200 mostrou valores altos de RU e pela simplificação da técnica resultou no mais vantajoso.

Palavras-chave: Resistência de união, Pino intrarradicular, Agente de irrigação 


\title{
BOND STRENGTH OF DIFFERENT LUTING CEMENTS TO DENTINE SUBMITTED TO DIFFERENT PRETREATMENT PROTOCOLS
}

\begin{abstract}
This study aimed to evaluate the bond strength (BS) of different systems used to luting fiberglass post (GFP) to dentin submitted to different cleaning protocols. Seventy-two human teeth with similar length roots were randomly divided into two groups $(n=36)$, according to the pretreatment protocol, conventional $(\mathrm{NaOCl} 2.5 \%+$ EDTA $17 \%)$ or activated ( $\mathrm{NaOCl} 2.5 \%$ + passive ultrasonic irrigation) and then, in three subgroups for each protocol $(n=12)$ according to the type of cement evaluated (Civ: Meron; Ultimate: RelyX Ultimate and U200: RelyX U200). After standardized preparation of the post space, the root canal receives treatment with an adhesive system for conventional dual resin cement and no treatment for other types of cement. Rhodamine has incorporated into the cementation system prior to GFP cementation. After that, slices of the cervical, middle and apical thirds of the post space were prepared and analyzed using a pushout test and confocal laser microscopy scanning (CLMS). ANOVA 3 way and Fisher's LSD test showed that there was no statistically significant difference between cleaning protocols ( $p=0.102$ ); However, among cements, the results of BS were similar only at the apical third, while at the medium and cervical thirds, Ultimate and U200 showed similar and superior results to CIV $(p<0.001)$. A percentage of penetration of cements into dentinal tubules was assessed using the Kruskal-Wallis test and showed no statistically significant difference between the factors $(P=0.076)$. The two cleaning protocols show effective effects and the RelyX U200 resin cement showed high values of BS and due to technical handling, result to be more advantageous.
\end{abstract}

Keywords: Bond Strength, Fiber post, Irrigation agent 